\title{
Conjugated linoleic acid (CLA) content of French Emmental cheese: effect of the season, region of production, processing and culinary preparation
}

\author{
Jean-François CHAMBA ${ }^{\mathrm{a} *}$, Jean-Michel CHARDIGNY,e, Silke GNÄDIG ${ }^{\mathrm{b}}$, \\ Eric PERREARDa, Stéphane CHAPPAZc , Reinhart RICKERT ${ }^{d}$, \\ Hans STEINHART ${ }^{d}$, Jean-Louis SÉBÉDIOb,e \\ a Institut Technique Français du Fromage, 419 route des champs laitiers, BP 30 , \\ 74801 La Roche sur Foron cedex, France \\ b INRA-CRNH Auvergne, UMR1019, 63000 Clermont-Ferrand, France \\ c INRA-ENESAD, UMR1129 FlaViC, 21065 Dijon, France \\ d ITFF, Laboratoire Analyses Alimentaires et Recherche Fromagère, rue de la Laiterie, \\ 25620 Mamirolle, France \\ e Universität Hamburg, Institut für Lebensmittelchemie, Grindelallee 117, 20146 Hamburg, Germany
}

Received 13 April 2006 - Accepted 18 October 2006

\begin{abstract}
Conjugated linoleic acid (CLA), and especially rumenic acid, are isomers of linoleic acid which have a great potential in human nutrition for their beneficial properties. The most important sources of natural CLA are milk and dairy products such as cheese. This study was delineated to assess the effects of sampling according to the cheese wheel, the seasonal and regional influence on CLA content in French Emmental cheese and, finally, the effects of culinary preparation of three different dishes (gratin, béchamel sauce and cheese fondue) and processed cheese. The rumenic acid content of Emmental cheese varied between $0.6 \%$ and $1.5 \%$ of total fatty acids according to the season and region of production, and appeared homogeneous through the cheese wheel. The culinary utilization and processing did not change the rumenic acid content of Emmental cheese.
\end{abstract}

\section{CLA / milk / processed cheese / cooking / Emmental cheese}

摘要 - 生产季节、产地、干酪的在制和烹调方法对法国埃门塔尔干酪中共轭亚油酸 (CLA) 含量的影响。共轭亚油酸 (CLA) 特别是瘤胃酸是亚油酸的一组构象和位置异构体, 对人体 具有重要的生理功能。乳和乳制品是共轭亚油酸最重要的来源。本文研究了轮状的法国埃 门塔尔干酪 (Emmental cheese) 的不同采样部位、干酪的生产季节和产地对干酪中共轭亚油 酸含量的影响, 同时还研究了 3 种烹调方法 gratin (用面包屑或干酪丝撒在菜面上烘烤的烹 调物), béchamel sauce (面粉, 黄油, 牛奶, 干酪及各种香料调味酱) 和 fondue (酒味乳酪 制品) 以及干酪的再制对其中共轭亚油酸的影响。根据对不同生产季节、不同产地的干酪样 品及轮状埃门塔尔干酪不同部位的采样分析结果表明, 其中瘤胃酸占总脂肪酸的含量变化 范围在 $0.6 \%-1.5 \%$ 。烹调方法和干酪的再制过程对干酪中瘤胃酸的含量没有影响。

共轭亚油酸 / 牛奶 / 再制干酪 / 烹调 / 埃门塔尔干酪

\footnotetext{
* Corresponding author (通讯作者): jf.chamba@it2f.com
} 
Résumé - Teneur en acide linoléique conjugué (CLA) dans l'Emmental français : effet de la saison, de la zone de production, de la fabrication et du mode de préparation culinaire. Les isomères conjugués de l'acide linoléique (CLA) et, en particulier, l'acide ruménique $\left(\mathrm{C}_{18: 2} 9\right.$ cis 11 trans) possèdent des effets bénéfiques d'un grand intérêt en nutrition humaine. Le lait et les produits laitiers, tels que les fromages, sont d'importantes sources naturelles d'acide ruménique. Ce travail avait pour but d'en établir la répartition au sein de la meule de fromage, d'étudier l'influence de la saison et de l'origine régionale sur la teneur en CLA de l'Emmental français et enfin, de mesurer les effets de son utilisation, soit en cuisine dans la préparation de sauce béchamel, de gratin et de fondue, soit dans la fabrication de fromage fondu. La teneur de l'Emmental français en acide ruménique varie de $0,6 \%$ à $1,5 \%$ de la teneur totale en acide gras selon la saison et la région de production, elle est homogène au sein de la meule de fromage. Aucune modification significative de la teneur en CLA n'est observée lors de l'utilisation de l'Emmental, aussi bien pour les trois préparations culinaires que pour la fabrication de fromage fondu.

\section{CLA / lait / fromage fondu / préparation culinaire / Emmental}

\section{INTRODUCTION}

Conjugated linoleic acid (CLA) refers to mixtures of positional and geometrical isomers of linoleic acid with a conjugated double bond system [9, 17]. Since the last decade beneficial properties have been revealed in various animal experiments induced by diets containing CLA $[1,13,16]$. The most important sources of natural CLA in human nutrition are milk and dairy products. The major CLA isomer is 9c11t-C18:2, also called rumenic acid [11]. 9c11t-C18:2 is formed by bioconversion of polyunsaturated fatty acids (PUFA) in the rumen and by $\Delta 9$-desaturation of vaccenic acid (11t18:1) in the mammary gland of the lactating cow $[6,8]$.

Various factors have been reported to modulate the CLA content in milk [2]. As a consequence, regional variations due to cows' diet and breed have already been reported in butterfat $[5,12]$. However, the CLA content in Emmental cheese, including putative differences according to various parts of the wheel, as well as regional variations, have not yet been extensively studied. Moreover, the relationship between the CLA content and different parameters of food processing in dairy products has been discussed controversially [20,22, 23].

In the present study, we assessed the effects of (i) sampling in the wheel, (ii) the regional and seasonal influence on CLA content in French Emmental cheese, (iii) the influence of cooking Emmental and (iv) the preparation of processed cheese on the rumenic acid content.

\section{MATERIALS AND METHODS}

\subsection{Chemicals}

All solvents were purchased from SDS (Peypin, France) and hexane was purified by distillation before use. Chemicals were obtained from Sigma-Aldrich (L'Isle d'Abeau, France).

\subsection{Sampling in the wheel}

First, a block of cheese was cut according to the radius of the wheel. Then, nine samples were extracted $2 \mathrm{~cm}$ (without crust) from the periphery of the two sides (faces) and the heel of the cheese block. Six samples were obtained at the core level.

\subsection{Regional variations in CLA in Emmental cheese from France}

Forty-five Emmental cheese samples were collected from two typical production areas, i.e. traditional (Savoy and FrancheComté - SFC, $\mathrm{n}=28$ ) and intensive production areas (Brittany, $n=17$ ). In the former region, cows were mainly Red Pie (Montbéliarde, Abondance), maintained under a continental climate, and fed pasture in summer and hay in winter. On the other hand, cows in Brittany were mainly Black Pie, maintained under an Atlantic climate and fed grass and corn silage.

\subsection{Preparation of cheese and dishes}

To test the effect on the CLA content during culinary utilization, the Emmental 
cheese was used in different dishes. The preparation of the dishes was carried out at the Maison du Goût (Bourg-en-Bresse, France) under standardized repeatable conditions. Three typical French dishes were chosen to determine the stability of CLA in cheese during homemade cooking. The types of dishes were selected in order to expose the cheese to moderate or high temperatures for variable durations. All dishes were prepared from the same cheese, grated before use. One sample of the dish was analyzed as raw material, uncooked, to measure the CLA content before processing:

- "Purée de pommes de terre gratinée (Gratin)": mashed potatoes were covered with $9 \mathrm{~g}$ of grated cheese and grilled at $225^{\circ} \mathrm{C}$ for $21 \mathrm{~min}$.

- "Sauce Béchamel": industrially-produced Béchamel sauce was mixed with $7.5 \mathrm{~g}$ of grated cheese. The sauce was slightly heated for $10 \mathrm{~min}$ up to $78^{\circ} \mathrm{C}$ until the cheese melted.

- "Fondue Savoyarde (cheese fondue)": the grated cheese was melted in white wine for $5 \mathrm{~min}$ at $98^{\circ} \mathrm{C}$.

The study was done using two cheese samples, one manufactured in a pilot-scale unit and one industrially-produced Emmental. The different dishes were prepared in triplicate.

\subsection{Fabrication of processed cheese}

The processing of cheese spread was carried out at the ITFF (La Roche sur Foron, France) under standardized repeatable conditions. Emmental cheese was milled, mixed with melting salts and homogenized. The mixture was melted in vacuum vessels, additionally heated for 5 or $10 \mathrm{~min}$ and packed. The cheese spread was prepared using two different cheeses, one cheese produced in a pilot-scale unit and one in an industrial plant.

The manufacturing time $(0,5$ or $10 \mathrm{~min})$ and the processing temperature (75 or $100{ }^{\circ} \mathrm{C}$ ) were the two studied parameters. Two independent repetitions for each sample were carried out.

\subsection{Lipid extraction}

Liquid samples were lyophilized before extraction. The other samples were minced. A defined quantity of sample was weighed and the lipid content was extracted according to Sehat et al. [19]. The extracted lipids were stored at $-80{ }^{\circ} \mathrm{C}$ until methylation.

\subsection{Methylation}

The CLA content was determined using C23:0 methyl ester as the internal standard. A defined aliquot (containing about 12$15 \mathrm{mg}$ lipid) of the extracted lipids and the internal standard solution were mixed. Fatty acid methyl esters (FAME) were prepared as described [10] and extracted twice by $2 \mathrm{~mL}$ of hexane.

\subsection{GC-Analyses}

FAME were analyzed using a Hewlett Packard HP 5890 Series II (Hewlett Packard Ltd, Wokingham, UK) equipped with a split/splitless injector (using split mode split ratio 1:20) and a flame ionization detector. The temperature of both the injector and detector was $250^{\circ} \mathrm{C}$. Hydrogen was used as the carrier gas. The analyses were performed using a CPSil88-fused silica capillary column $(100 \mathrm{~m} \times 0.25 \mathrm{~mm}$ I.D., $0.25 \mu \mathrm{m}$ film thickness, Chrompack, Middleburg, The Netherlands) using a temperature program as described by Sehat et al. [19] $\left(70{ }^{\circ} \mathrm{C}(4 \mathrm{~min}), 13^{\circ} \mathrm{C} \cdot \mathrm{min}^{-1}\right.$ to $175^{\circ} \mathrm{C}$ $(27 \mathrm{~min}), 4^{\circ} \mathrm{C} \cdot \mathrm{min}^{-1}$ to $\left.215^{\circ} \mathrm{C}(31 \mathrm{~min})\right)$. Data were collected using a Borwin workstation (JMBS Developments, Fontaine, France) including an acquisition interface, software and a computer.

\subsection{Statistical analysis}

Statistical analysis was carried out using the NCSS-software (Kaysville, Utah). The Kruskall \& Wallis non-parametric test was used to determine differences between the groups. A $P$-value less than 0.05 was considered as statistically significant. 
Table I. Fatty acid profile of Emmental cheese according to the sampling in the wheel.

\begin{tabular}{lrr}
\hline & Periphery $(\mathrm{n}=9)$ & Core $(\mathrm{n}=6)$ \\
\hline C4:0 & $4.6 \pm 0.2$ & $4.4 \pm 0.2$ \\
C6:0 & $2.7 \pm 0.1$ & $2.6 \pm 0.1$ \\
C8:0 & $1.5 \pm 0.2$ & $1.6 \pm 0.1$ \\
C10:0 & $3.5 \pm 0.3$ & $3.5 \pm 0.1$ \\
C12:0 & $3.8 \pm 0.1$ & $3.9 \pm 0.1$ \\
C14:0 & $11.7 \pm 0.1$ & $11.7 \pm 0.1$ \\
C14:1 & $0.9 \pm 0.1$ & $0.9 \pm 0.2$ \\
C15:0 & $1.2 \pm 0.0$ & $1.2 \pm 0.0$ \\
C16:0 & $27.2 \pm 0.1$ & $27.3 \pm 0.0$ \\
C16:1 & $1.5 \pm 0.1$ & $1.5 \pm 0.1$ \\
C17:0 & $0.7 \pm 0.1$ & $0.7 \pm 0.0$ \\
C18:0 & $11.1 \pm 0.1$ & $11.1 \pm 0.1$ \\
9t-C18:1 & $0.2 \pm 0.0$ & $0.2 \pm 0.0$ \\
11t-C18:1 & $2.8 \pm 0.1$ & $2.8 \pm 0.1$ \\
9c-C18:1 & $21.9 \pm 0.1$ & $22.0 \pm 0.1$ \\
9c12c-C18:2 & $1.8 \pm 0.1$ & $1.8 \pm 0.0$ \\
9c11t-C18:2 & $1.1 \pm 0.0$ & $1.1 \pm 0.0$ \\
SFA & $68.7 \pm 0.1$ & $68.7 \pm 0.0$ \\
MUFA* & $24.2 \pm 0.1$ & $24.3 \pm 0.0$ \\
PUFA & $2.9 \pm 0.0$ & $2.9 \pm 0.0$ \\
TFA & $4.1 \pm 0.0$ & $4.1 \pm 0.0$ \\
\hline & & \\
\hline & cis &
\end{tabular}

*: cis isomers only.

\section{RESULTS AND DISCUSSION}

\subsection{Wheel zonal content}

The fatty acid composition of different samples from the same wheel (core and peripheral zones) is detailed in Table I. No significant difference appeared for any fatty acid. Rumenic acid represented $1.1 \%$ of total fatty acids, while vaccenic acid represented about $2.8 \%$ of total fatty acids. Since sampling did not alter the fatty acid profile, it was possible to compare samples of different origin, without generating a possible bias of sampling.

\subsection{Regional and seasonal variations}

Table II presents the fatty acid profile of Emmental cheeses samples in winter and summer, and in the Brittany or Savoy, Franche-Comté (SFC) regions. The influence of the place where the cheese (and raw milk) was produced appeared of major importance. Moreover, the season was also of importance. Rumenic acid content was the greatest in summer compared with winter and for samples from SFC compared with those from Brittany. A similar trend was observed for the vaccenic acid content. At the same time, the content of saturated fatty acids was decreased, whereas the content of cis monounsaturated fatty acids was less altered. Such seasonal effects have already been observed on butter [12] and cow's milk [3] or sheep's milk [15]. Compared with the data from Collomb and Buhler [3] obtained in Switzerland, the rumenic acid content in our French SFC samples was higher (1.00 vs. $0.64 \mathrm{mg} \cdot \mathrm{g}^{-1}$ fat in winter), which might be due to various parameters, including cow breeds or feeding strategies [4]. The difference in summer was less significant (1.50 vs. $1.44 \mathrm{mg} \cdot \mathrm{g}^{-1}$ fat).

\subsection{Effect of cooking and grilling}

The rumenic acid content remained unchanged $(P>0.05)$ during culinary utilization (grilling and cooking), as shown in Table III. For example, the rumenic acid content in the "Gratin" prepared with industrial cheese was determined as being $7.3 \mathrm{mg} \cdot \mathrm{g}^{-1}$ fat and $7.4 \pm 0.3 \mathrm{mg} \cdot \mathrm{g}^{-1}$ fat before and after the exposure of the dish to high temperatures, respectively. Similarly, the "Sauce Béchamel" prepared with industrial cheese contained $6.8 \mathrm{mg}$ rumenic acid. $\mathrm{g}^{-1}$ fat and $6.8 \pm 0.1 \mathrm{mg}$ rumenic acid $\cdot \mathrm{g}^{-1}$ fat before and after the exposure of the dish to a moderate temperature, respectively. Furthermore, no differences in the fatty acid composition of the dishes before or after cooking or grilling were detected (data not shown).

Our present results indicate that rumenic acid in cheese during culinary preparations has a good thermal stability, in agreement with Shantha et al. [21]. The exposure of 
Table II. Fatty acid profile (\%) of Emmental cheese samples in SFC $(n=28)$ and Brittany $(n=17)$ produced either in winter or summer. Values are means \pm SD.

\begin{tabular}{|c|c|c|c|c|c|c|}
\hline & \multicolumn{2}{|c|}{ Winter } & \multicolumn{2}{|c|}{ Summer } & \multicolumn{2}{|c|}{ Statistics } \\
\hline & SFC & Brittany & SFC & Brittany & $\begin{array}{l}\text { Winter vs. } \\
\text { Summer }\end{array}$ & $\begin{array}{c}\text { SFC } \\
\text { vs. Brittany }\end{array}$ \\
\hline $\mathrm{C} 4: 0$ & $4.4 \pm 0.03$ & $4.5 \pm 0.02$ & $4.4 \pm 0.03$ & $4.5 \pm 0.03$ & & $*$ \\
\hline C6:0 & $2.6 \pm 0.02$ & $2.7 \pm 0.01$ & $2.4 \pm 0.02$ & $2.6 \pm 0.01$ & $*$ & $*$ \\
\hline C8:0 & $1.5 \pm 0.01$ & $1.6 \pm 0.01$ & $1.4 \pm 0.02$ & $1.5 \pm 0.01$ & $*$ & $*$ \\
\hline C10:0 & $3.3 \pm 0.06$ & $3.4 \pm 0.02$ & $3.0 \pm 0.05$ & $3.2 \pm 0.01$ & $*$ & $*$ \\
\hline C12:0 & $3.8 \pm 0.08$ & $3.9 \pm 0.03$ & $3.4 \pm 0.05$ & $3.6 \pm 0.05$ & $*$ & $*$ \\
\hline C14:0 & $12.4 \pm 0.18$ & $11.7 \pm 0.09$ & $11.3 \pm 0.09$ & $11.5 \pm 0.13$ & $*$ & \\
\hline C14:1 & $0.9 \pm 0.02$ & $1.0 \pm 0.03$ & $0.9 \pm 0.02$ & $1.0 \pm 0.02$ & $*$ & $*$ \\
\hline C15:0 & $1.3 \pm 0.01$ & $1.1 \pm 0.01$ & $1.3 \pm 0.01$ & $1.3 \pm 0.02$ & $*$ & $*$ \\
\hline C16:0 & $31.6 \pm 0.66$ & $32.1 \pm 0.66$ & $27.0 \pm 0.27$ & $29.5 \pm 0.46$ & $*$ & $*$ \\
\hline C16:1 & $1.8 \pm 0.08$ & $1.9 \pm 0.06$ & $1.6 \pm 0.05$ & $2.1 \pm 0.09$ & & $*$ \\
\hline C17:0 & $0.8 \pm 0.01$ & $0.7 \pm 0.05$ & $0.8 \pm 0.01$ & $0.8 \pm 0.01$ & & $*$ \\
\hline C18:0 & $9.4 \pm 0.22$ & $10.4 \pm 0.26$ & $11.3 \pm 0.16$ & $11.2 \pm 0.23$ & $*$ & \\
\hline 9t-C18:1 & $0.2 \pm 0.01$ & $0.2 \pm 0.02$ & $0.2 \pm 0.01$ & $0.2 \pm 0.01$ & $*$ & $*$ \\
\hline 11t-C18:1 & $2.1 \pm 0.27$ & $1.5 \pm 0.12$ & $3.5 \pm 0.12$ & $2.4 \pm 0.09$ & $*$ & $*$ \\
\hline $9 \mathrm{c}-\mathrm{C} 18: 1$ & $19.1 \pm 0.43$ & $19.7 \pm 0.42$ & $22.4 \pm 0.25$ & $21.0 \pm 0.41$ & $*$ & \\
\hline 9c12c-C18:2 & $1.7 \pm 0.04$ & $1.4 \pm 0.02$ & $1.6 \pm 0.03$ & $1.2 \pm 0.01$ & $*$ & $*$ \\
\hline C18:3n-3 & $0.9 \pm 0.04$ & $0.5 \pm 0.05$ & $0.9 \pm 0.04$ & $0.6 \pm 0.02$ & & $*$ \\
\hline 9c11t-C18:2 & $1.0 \pm 0.13$ & $0.6 \pm 0.04$ & $1.5 \pm 0.06$ & $1.0 \pm 0.03$ & $*$ & $*$ \\
\hline SFA & $72.0 \pm 0.78$ & $73.0 \pm 0.54$ & $67.2 \pm 0.25$ & $70.3 \pm 0.43$ & $*$ & $*$ \\
\hline MUFA $^{a}$ & $21.8 \pm 0.39$ & $22.6 \pm 0.36$ & $24.8 \pm 0.22$ & $24.1 \pm 0.33$ & $*$ & \\
\hline PUFA & $2.9 \pm 0.06$ & $2.2 \pm 0.05$ & $2.7 \pm 0.06$ & $2.1 \pm 0.1$ & & $*$ \\
\hline TFA & $3.3 \pm 0.40$ & $2.3 \pm 0.16$ & $5.2 \pm 0.17$ & $3.5 \pm 0.12$ & * & * \\
\hline
\end{tabular}

a : cis isomers only.

$*: P<0.05$.

SFA: saturated fatty acids; MUFA: monounsaturated fatty acids; PUFA: polyunsaturated fatty acids; TFA: trans fatty acids.

milk to moderate heating temperatures (up to $200^{\circ} \mathrm{C}$ ) had no effect on the rumenic acid content. Only heating milk at $225{ }^{\circ} \mathrm{C}$ for 15 min decreased the $9 \mathrm{c} 11 \mathrm{t}-\mathrm{C} 18: 2$ content from $1.7 \%$ to $1.1 \%$ of total fatty acids [18].

\subsection{Preparation of processed cheese}

The processing of cheese spread by heating at $75{ }^{\circ} \mathrm{C}$ with and without additional heating time did not change the rumenic acid content (Tab. IV). Similar results were observed for a processing temperature of $100{ }^{\circ} \mathrm{C}$ without additional heating time. Only for the highest processing temperature $\left(100^{\circ} \mathrm{C}\right)$ and the longest manufacturing time (additional heating time, $10 \mathrm{~min}$ ) a small but not significant decrease in the rumenic acid content was found. The rumenic acid content decreased from $8.2 \pm$ $0.1 \mathrm{mg} \cdot \mathrm{g}^{-1}$ fat to $7.0 \pm 0.8 \mathrm{mg} \cdot \mathrm{g}^{-1}$ fat $(P<0.2)$. However, the different processing 
Table III. Rumenic acid content in cooked and grilled dishes (mean \pm SD).

\begin{tabular}{lcc}
\hline & \multicolumn{2}{c}{ CLA content in $\mathrm{mg} \cdot \mathrm{g}^{-1}$ fat } \\
\cline { 2 - 3 } & $\begin{array}{c}\text { cheese, made } \\
\text { in pilot-scale unit }\end{array}$ & $\begin{array}{c}\text { cheese, made } \\
\text { in industrial plant }\end{array}$ \\
\hline Gratin, raw [n=1] & 8.5 & 7.3 \\
Gratin [n = 3] & $7.3 \pm 0.9$ & $7.4 \pm 0.3$ \\
Sauce Béchamel, raw [n =1] & 6.4 & 6.8 \\
Sauce Béchamel [n $=3]$ & $6.0 \pm 0.1$ & $6.8 \pm 0.1$ \\
Fondue Savoyarde, raw [n=1] & 7.8 & 9.2 \\
Fondue Savoyarde [n $=3]$ & $7.8 \pm 0.2$ & $8.7 \pm 0.1$ \\
\hline
\end{tabular}

Table IV. Rumenic acid content in processed cheese using different processing conditions (mean $[\mathrm{n}=2] \pm \mathrm{SD}$ ).

\begin{tabular}{lcc}
\hline $\begin{array}{l}\text { Processing } \\
\text { temperature } \\
\left({ }^{\circ} \mathrm{C}\right)\end{array}$ & $\begin{array}{c}\text { Additional } \\
\text { heating } \\
\text { time }(\mathrm{min})\end{array}$ & $\begin{array}{c}\text { CLA content } \\
\left(\mathrm{mg} \cdot \mathrm{g}^{-1} \text { fat }\right)\end{array}$ \\
\hline control & 0 & $8.2 \pm 0.1$ \\
75 & 5 & $8.4 \pm 0.6$ \\
75 & 0 & $8.1 \pm 0.5$ \\
100 & 10 & $7.0 \pm 0.8$ \\
100 & \\
\hline
\end{tabular}

conditions did not induce any significant difference in the fatty acid composition (data not shown). Such lack of rumenic acid content alteration is in opposition to former published results. Garcia-Lopez et al. [7] reported a slight increase in the CLA content from $9.5 \mathrm{mg} \cdot \mathrm{g}^{-1}$ fat to $10.7 \mathrm{mg} \cdot \mathrm{g}^{-1}$ fat during the processing of cheese. This effect could be related to their processing conditions, which were not further detailed. No direct comparison between the different fabrication conditions can be made to explain the discrepancies. But using American cheese instead of Cheddar cheese for the preparation of processed cheese, the CLA content remained unchanged [22]. It seems possible that the increase in CLA during processing could depend on the type of cheese, related to differences in cheese processing.

On the other hand, Luna et al. [14] also reported no influence of processing on CLA content and profile during processing of portions and slices. The temperatures considered $\left(<150{ }^{\circ} \mathrm{C}\right)$ in both the present study and the one by Luna et al. probably explain this discrepancy with what was observed with high-temperature $\left(\geq 200^{\circ} \mathrm{C}\right)$ treatments [18].

\section{CONCLUSION}

In conclusion, the culinary utilization of cheese and the fabrication of processed cheese did not change the rumenic acid content in Emmental cheese, confirming the importance of its content in raw milk. However, the rumenic acid content depends on the region of production, probably in connection with the dietary habits of the cows. Furthermore, the rumenic acid content of Emmental cheese appeared constant, whatever the place of the sample in the wheel.

Acknowledgments: S. Gnädig was funded by a Marie Curie Fellowship of the European Union (FAIR-CT98-5071). The authors thank the French Emmental Cheese Union (SIGF) for financial support. This work was also supported by a grant from the French Ministry for Research (AQS 1998).

\section{REFERENCES}

[1] Belury M.A., Dietary conjugated linoleic acid in health: physiological effects and mechanisms of action, Ann. Rev. Nutr. 22 (2002) 505-531. 
[2] Chilliard Y., Ferlay A., Rouel J., Lamberet G., A review of nutritional and physiological factors affecting goat milk lipid synthesis and lipolysis, J. Dairy Sci. 86 (2003) 17511770.

[3] Collomb M., Buhler T., Analyse de la composition en acides gras de la graisse de lait. I. Optimisation et validation d'une méthode générale à haute résolution, Mitt. Lebensm. Hyg. 91 (2000) 306-332.

[4] Collomb M., Bütikofer U., Spahni M., Jeangros B., Bosset J.O., Composition en acides gras et en glycérides de la matière grasse du lait de vache en zone de montagne et de plaine, Sci. Alim. 19 (1999) 97-110.

[5] Collomb M., Sieber R., Bütikofer U., CLA isomers in milk fat from cows fed diets with high levels of unsaturated fatty acids, Lipids 39 (2004) 355-364.

[6] Fritsche J., Steinhart H., Amounts of conjugated linoleic acid (CLA) in German foods and evaluation of daily intake, Z. Lebensm. Unters. Forsch. A 206 (1998) 77-82.

[7] Garcia-Lopez S., Echeverra E., Tsui I., Balch B., Changes in the content of conjugated linoleic acid (CLA) in processed cheese during processing, Food Res. Int. 27 (1994) 61-64.

[8] Griinari J.M., Corl B.A., Lacy S.H., Chouinard P.Y., Nurmela K.V., Bauman D.E., Conjugated linoleic acid is synthesized endogenously in lactating dairy cows by Delta(9)desaturase, J. Nutr. 130 (2000) 2285-2291.

[9] Ha Y.L., Grimm N.K., Pariza M.W., Anticarcinogens from fried ground beef: heataltered derivatives of linoleic acid, Carcinogenis 8 (1987) 1881-1887.

[10] Kramer J.K.C., Fellner V., Dugan M.E.R., Sauer F.D., Mossoba M.M., Yurawecz M.P., Evaluating acid and base catalysts in the methylation of milk and rumen fatty acids with special emphasis on conjugated dienes and total trans fatty acids, Lipids 32 (1997) $1219-1228$.

[11] Kramer J.K.G., Parodi P.W., Jensen R.G., Mossoba M.M., Yurawecz M.P., Adlof R.O., Rumenic acid: A proposed common name for the major conjugated linoleic acid isomer found in natural products, Lipids 33 (1998) 835.

[12] Ledoux M., Chardigny J.M., Darbois M., Soustre Y., Sebedio J.L., Laloux L., Fatty acid composition of French butters, with special emphasis on conjugated linoleic acid
(CLA) isomers, J. Food Comp. Anal. 18 (2005) 409-425.

[13] Lee K.W., Lee H.J., Cho H.Y., Kim Y.J., Role of the conjugated linoleic acid in the prevention of cancer, Crit. Rev. Food Sci. Nutr. 45 (2005) 135-144.

[14] Luna P., De La Fuente M.A., Juarez M., Conjugated linoleic acid in processed cheeses during the manufacturing stages, J. Agric. Food Chem. 53 (2005) 2690-2695.

[15] Nudda A., McGuire M.A., Battacone G., Pulina G., Seasonal variation in conjugated linoleic acid and vaccenic acid in milk fat of sheep and its transfer to cheese and ricotta, J. Dairy Sci. 88 (2005) 1311-1319.

[16] Pariza M.W., Perspective on the safety and effectiveness of conjugated linoleic acid, Am. J. Clin. Nutr. 79 (2004) 1132S-1136S.

[17] Pariza M.W., Hargraves W.A., A beefderived mutagenesis modulator inhibits initiation of mouse epidermal tumors by 7,12dimethylbenz[a]anthracene, Carcinogenesis 6 (1985) 591-593.

[18] Precht D., Molkentin J., Vahlendick M., Influence of the heating temperature on the fat composition of milk fat with the emphasis on cis-/trans-isomerization, Nahrung 43 (1999) 25-33.

[19] Sehat N., Kramer J.K.G., Mossoba M.M., Yurawecz M.P., Roach J.A.G., Eulitz K., Morehouse K.M., Ku Y., Identification of conjugated linoleic acid isomers in cheese by gas chromatography, silver ion high performance liquid chromatography and mass spectral reconstructed ion profiles. Comparison of chromatographic elution sequences, Lipids 33 (1998) 963-971.

[20] Shantha N.C., Decker E.A., Conjugated linoleic acid concentrations in cooked beef containing antioxidants and hydrogen donors, J. Food Lipids 2 (1995) 7-64.

[21] Shantha N.C., Decker E.A., Ustunol Z., Conjugated linoleic acid concentration in processed cheese, J. Am. Oil Chem. Soc. 69 (1992) 425-428.

[22] Shantha N.C., Crum A.D., Decker E.A., Evaluation of conjugated linoleic acid concentrations in cooked beef, J. Agric. Food Chem. 42 (1994) 1757-1760.

[23] Yang L., Leung L.K., Huang Y., Chen Z.Y., Oxidative stability of conjugated linoleic acid isomers, J. Agric. Food Chem. 48 (2000) 3072-3076. 